\title{
Morphology control and applications of ceramic materials synthesized in aqueous solutions
}

\author{
Hidero UNUMA ${ }^{\dagger}$ \\ Graduate School of Science and Engineering, Yamagata University, 4-3-16 Jonan, Yonezawa, Yamagata 992-8510, Japan
}

\begin{abstract}
Ceramic synthesis in aqueous solutions, referred to as aqueous solution processing in this article, is attracting much attention as its high potentiality of controlling morphology, composition, and functions are revealed by recent pioneering works. A diverse range of chemical reactions and physical phenomena are available to create new materials that has been difficult to be processed by other techniques. Mild processing conditions inherent to aqueous solution processes have made it possible to define morphology and composition of the products in elaborate ways, to hybridize ceramic with organic substances or metal nanoparticles, and to contribute to economical and environmental issues of ceramic industry. Among many beneficial aspects of aqueous solution processing, this article spotlights the categorization of chemical reactions used for thin film deposition, up to date outlines of enzyme-mediated techniques, and recent attempts of the application. The products of aqueous solution processing should find applications in vast fields of technology as its inherent advantages are explored.
\end{abstract}

(C2013 The Ceramic Society of Japan. All rights reserved.

Key-words : Aqueous solution, Morphology control, Thin films, Enzyme

[Received July 10, 2013; Accepted August 24, 2013]

\section{Introduction}

Wet chemical synthesis has long been used in ceramics industry. Synthesis of alumina, $\mathrm{BaTiO}_{3}$, and ferrite powders are good examples exhibiting excellent potentiality of wet chemical synthesis in guaranteeing precise morphology and chemical composition. Hydrothermally grown quartz single crystal may also be another example that has been widely used in industry. On another front, along with the growing interest in developing "biomimetic" or "bio-inspired" ceramic processes, numerous techniques have newly been proposed to control the morphology and structure of ceramic materials synthesized in aqueous solutions. These emerging new techniques will be referred to as "aqueous solution processing" in this article to distinguish them from traditional, well-established wet chemical processes.

One advantage of the aqueous solution processing over other processing techniques may be availability of a diverse range of chemical reactions and physical phenomena including acid-base reactions, redox reactions, self assembly, intercalation-deintercalation, selective adsorption, electrochemical reactions, liquidliquid phase separation, and biochemical reactions, just to name a few. This variety of expedients make possible to control morphology of the products, define structure at microscopic and macroscopic scales, hybridize ceramics with organic polymers or metals, and synthesize ceramics under mild temperatures and pressures. The mild temperature and pressure conditions should contribute not only to economical and environmental issues but to creating novel materials because temperaturesensitive substances such as proteins become readily available in ceramic synthesis.

One of the most extensively studied techniques in the aqueous solution processing may be ceramic thin film deposition. The key aspect of the thin film deposition is the control of the nuclea-

Corresponding author: H. Unuma; E-mail: unuma@yz. yamagata-u.ac.jp tion rate of a solid in aqueous solution so that heterogeneous nucleation on pertinent substrates predominates. Then, subsequent crystal growth gives a layer of solid thin film on the substrates. The film deposition reactions usually proceed in a temperature range between room temperature and $373 \mathrm{~K}$, the boiling point of water. Thin films are therefore deposited in a way that metal coatings are deposited by electroless plating. Thin film deposition techniques from aqueous solutions have several advantages over other techniques such as sol-gel dip coating, CVD, or sputtering. For example, costly equipment is not necessary, further heat-treatment may be omitted, or film thickness is uniform even on complicated-shaped substrates. As these potential advantages are attractive from a viewpoint of practical application, numerous papers have been published including several comprehensive reviews. ${ }^{1)-5)}$

On the other hand, thin films deposited from aqueous solutions may sometimes contain water, have low crystallinity, or be less dense because those are not subjected to heat-treatment. These mean that the film quality may not always be satisfactory for certain applications. Still, aqueous solution processing has its competitive advantage as long as it can make thin films that cannot be realized otherwise.

In regard to the reduction of the effects on the environment, aqueous solution processing shall become more significant in industries. Synthesis of ceramic materials under mild temperatures can be achieved by the use of the assistance of enzymes, ${ }^{6}$ ) synthetic peptides, polymers, or simple molecules. Some enzymes catalyze chemical reactions that produce precipitants of metal ions such as ammonia, phosphoric acid, or carbonate ion, thereby precipitation of metal hydroxides, phosphates, or carbonates take place under mild temperatures. Some other enzymes, peptides, polymers and simple molecules interact with water-soluble metal complexes like titanium(IV) bis(ammonium lactato) dihydroxide (TiBALDH) to promote the hydrolysis of the complexes, causing prompt precipitation of the metal oxides. The precipitation occurs in the vicinity of these organic substances. As it is easy to immo- 


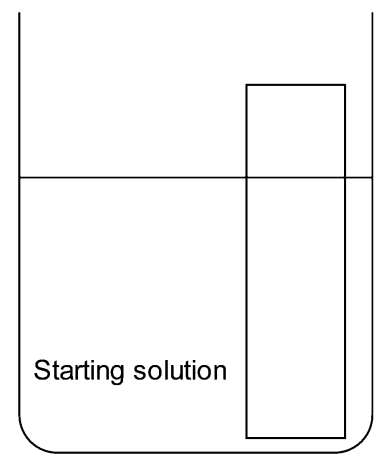

Spontaneous and slow precipitation of a solid
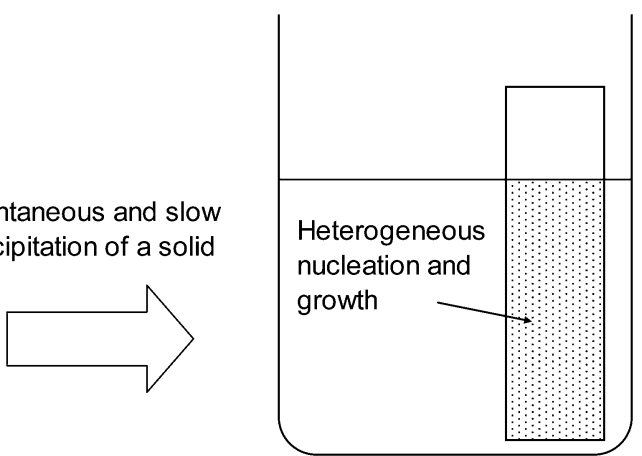

Fig. 1. Schematic representation of heterogeneous nucleation and growth of a thin film on a substrate.

bilize these organic substances onto various templates such as synthetic or natural polymers, glasses, or inorganic powders, it is easy to precipitate ceramic products to conform to the templates. Enzyme-mediated ceramic processing has been explored and some products are being applied to biosensing and biomedical remedies.

This article outlines some new directions of material developments via aqueous solution processing. The controllability of macroscopic morphology as well as nano-scaled structure is an advantageous feature of the process. Mild processing condition is another benefit. The products of aqueous solution processing shall find its application in vast field of technologies.

\section{Chemical reactions for thin film deposition in aqueous solutions}

When a solid precipitates out in a solution, the "nucleation and growth" mechanism is followed. If precipitating solid (A) is chemically compatible to another solid substrate (B) and the supersaturation degree is not so large, heterogeneous nucleation predominates so that the nuclei of solid A are formed on solid B/solution interface as schematically shown in Fig. 1. The subsequent growth of the solid A results in a layer of thin film. Niesen and DeGuire ${ }^{1), 2}$ classified the thin film deposition techniques into 4 categories; chemical bath deposition, liquid phase deposition, SILAR, and electroless deposition. Here, another classification of the processes is proposed based on the type of chemical reactions involved in the film deposition processes; (1) redox reaction process, (2) acid-base reaction process, and (3) ligand exchange reaction process.

Redox reaction process involves the change of the oxidation number of a metal ion dissolved in a solution. It is a general tendency that a metal ion is prone to precipitate as (hydr)oxide when its oxidation number is increased, i.e., oxidized. For example, when $\mathrm{Fe}^{2+}$ ions are oxidized to $\mathrm{Fe}^{3+}$, $\mathrm{FeOOH}$ or $\mathrm{Fe}_{3} \mathrm{O}_{4}$ precipitates out of the solution. Based on this tendency, Abe and coworkers developed a pioneering technique named "ferrite plating". 7),8) Although the film deposition does not take place in a homogeneous solution but it occurs when two solutions are mixed, this technique later evolved into "spin spray technique"9),10) that is capable of depositing high quality ferrite and $\mathrm{ZnO}$ films.

Based on the same principle, many other thin films including $\mathrm{SnO}_{2}, \mathrm{CeO}_{2}, \mathrm{MnO}_{2}, \mathrm{Co}_{3} \mathrm{O}_{4}, \mathrm{Fe}_{3} \mathrm{O}_{4}$ or $\mathrm{NiO}$ have been prepared. ${ }^{11-17)}$ For example, $\mathrm{SnO}_{2}$ thin films are deposited from a solution containing $\mathrm{SnCl}_{2} \cdot 2 \mathrm{H}_{2} \mathrm{O}$ and $\mathrm{KNO}_{3}$ at a temperature range from 333 to $353 \mathrm{~K}$. $\mathrm{SnO}_{2}$ precipitates according to the following reactions;

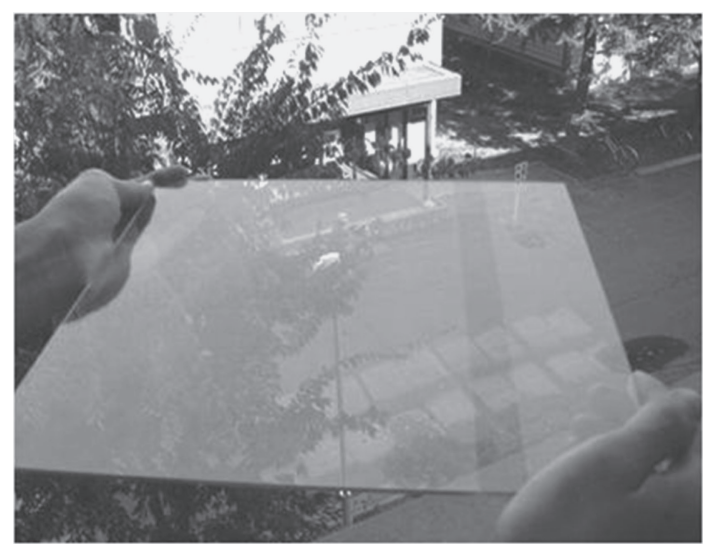

Fig. 2. Visual appearance of a $70 \mathrm{~nm}$-thick $\mathrm{SnO}_{2}$ thin film on a sheet of window pane glass. A narrow section on the right part was not coated purposely to show the contrast between coated and uncoated areas. Reprint from Ref. 18 with permission from Japan Soc. Powder and Powder Metallurgy.

$$
\begin{aligned}
& \mathrm{Sn}^{2+}+\mathrm{NO}_{3}{ }^{-}+2 \mathrm{H}^{+} \rightarrow \mathrm{Sn}^{4+}+\mathrm{NO}_{2}{ }^{-}+\mathrm{H}_{2} \mathrm{O} \\
& \mathrm{Sn}^{4+}+2 \mathrm{H}_{2} \mathrm{O} \rightarrow \mathrm{SnO}_{2}+4 \mathrm{H}^{+}
\end{aligned}
$$

In this case, nitrate ion $\left(\mathrm{NO}_{3}{ }^{-}\right)$acts as the oxidizing agent of $\mathrm{Sn}^{2+}$ ion. As reaction 2 is faster than 1 , reaction 1 is the ratedetermining step. So, $\mathrm{SnO}_{2}$ is deposited in the form of a film when the rate of reaction 1 is optimized. The factors affecting the rate of reaction 1 are the reactant concentration, reaction temperature and the choice of the oxidizing agent. Figure 2 shows an example of $70 \mathrm{~nm}$-thick $\mathrm{SnO}_{2}$ coating on a sheet of window pane glass prepared by above-mentioned method.

It is also possible to deposit nano-structured thin films with the aid of self-assembly of amphiphilic molecules as porogen. For example, dense $\gamma-\mathrm{MnO}_{2}$ thin films are deposited from a solution containing $0.01 \mathrm{~mol} / \mathrm{dm}^{3} \mathrm{MnCl}_{2} \cdot 4 \mathrm{H}_{2} \mathrm{O}$ and $0.1 \mathrm{~mol} / \mathrm{dm}^{3}$ $\mathrm{KBrO}_{3}$ by keeping this solution at $333 \mathrm{~K}$ for $24 \mathrm{~h}$, while lamellarstructured $\gamma-\mathrm{MnO}_{2}$ thin films are deposited by adding 0.1 $\mathrm{mol} / \mathrm{dm}^{3}$ of hexadecyltrimethyl ammonium chloride (CTAC). In this case, negatively-charged $\mathrm{MnO}_{2}$ clusters interact with positively-charged CTA cations and subsequent self assembly leads to lamellar structured thin films.

Acid-base reaction processes involve elevation of the $\mathrm{pH}$ of the starting solutions, by which metal ions in the solutions combine with hydroxide $\left(\mathrm{OH}^{-}\right)$ions to precipitate as oxide or hydroxide. Therefore, the main reactions are narrowly-defined acid-base neutralization. Acid-base reaction processes are often employed 
especially when metal ions are converted to oxides without forming stable hydroxide precursors, such as $\mathrm{ZnO}$ or ferrites. Particularly, the morphology of $\mathrm{ZnO}$ precipitate varies dramatically depending on many factors including the kind and concentration of the starting $\mathrm{Zn}$ salt, temperature, or additives. ${ }^{5), 19)}$ For instance, nanorod arrays and nanowires were deposited from a solution containing zinc nitrate $\left[\mathrm{Zn}\left(\mathrm{NO}_{3}\right)_{2}\right]$ and hexamethylenetetramine (HMT) by adjusting aforementioned conditions. A sophisticated sequence of reactions was proposed by Izaki et al. in which nitrate ions are slowly reduced by dimethylamineborane (DMAB) to nitrite ions so that the $\mathrm{pH}$ of the solution is accordingly raised and then precipitation of thin films of $\mathrm{ZnO}, \mathrm{Fe}_{3} \mathrm{O}_{4}$, and $\mathrm{CeO}_{2}{ }^{20)-22)}$ followed.

Ligand exchange reaction process, often denoted as liquid phase deposition (LPD) process and is based on Lewis acid-base reaction, can deposit metal oxide films in which the cations have small ionic sizes and high positive charges, such as $\mathrm{SiO}_{2}, \mathrm{TiO}_{2}$, and $\mathrm{ZrO}_{2}$ etc. Ions such as $\mathrm{Si}^{4+}, \mathrm{Ti}^{4+}$, or $\mathrm{Zr}^{4+}$ cannot be stably dissolved in water due to their high tendency to hydrolysis. However, pertinent ligands such as $\mathrm{F}^{-}$, citrate, lactate, or peroxide ions can stabilize these ions and also may undergo ligand exchange with water molecules so that precipitation is triggered. The first demonstration of this sort of process was the deposition of silica films in which hexafluorosilicate ions are converted to silica by an ligand exchange between $\mathrm{F}^{-}$and $\mathrm{H}_{2} \mathrm{O}$ [Eqs. (3) and (4)]. . $^{23}$

$$
\begin{aligned}
& \mathrm{H}_{2} \mathrm{SiF}_{6}+2 \mathrm{H}_{2} \mathrm{O} \Leftrightarrow 6 \mathrm{HF}+\mathrm{SiO}_{2} \\
& \mathrm{H}_{3} \mathrm{BO}_{3}+4 \mathrm{HF} \Leftrightarrow \mathrm{BF}_{4}^{-}+\mathrm{H}_{3} \mathrm{O}+2 \mathrm{H}_{2} \mathrm{O}
\end{aligned}
$$

Initially, equilibrium 3 is inclined to the left hand side. When boric acid is added to the solution, however, hydrogen fluoride is gradually consumed [Eq. (4)], which eventually shift the equilibrium 3 to the right hand side. Based on this principle, thin films of $\mathrm{SiO}_{2}, \mathrm{TiO}_{2},{ }^{24)-28)} \mathrm{ZrO}_{2},{ }^{29), 30)} \mathrm{WO}_{3},{ }^{31)}$ or $\mathrm{SrTiO}_{3}{ }^{32)}$ have been prepared starting from the stable complex ions in water.

Addition of $\mathrm{H}_{2} \mathrm{O}_{2}$ to a solution of $\left[\mathrm{Zn}\left(\mathrm{NH}_{3}\right)_{4}\right]^{2+}$ also triggers the ligand exchange between ammine- and peroxido- ligands and results in the precipitation of transparent thin films of zinc peroxide, $\mathrm{ZnO}_{2}$, which is then converted to transparent thin films of zinc oxide, $\mathrm{ZnO}$, by calcining at as low a temperature as $473 \mathrm{~K}^{33)}$ (Fig. 3).

A new process, which does not involve apparent chemical reactions, was proposed by Lange's group in which temperature dependence of $\mathrm{ZnO}$ solubility in ammonia solutions was sophisticatedly utilized. ${ }^{34)-37)}$ They found that the solubility of $\mathrm{ZnO}$ in ammonia solution inversely dependent on temperature; that is, $\mathrm{ZnO}$ dissolves more at lower temperatures. Therefore, once $\mathrm{ZnO}$ dissolution is saturated at room temperature, just heating the solution to $363 \mathrm{~K}$ produces $\mathrm{ZnO}$ thin films. A transistor device has been built up using this technique. ${ }^{38)}$
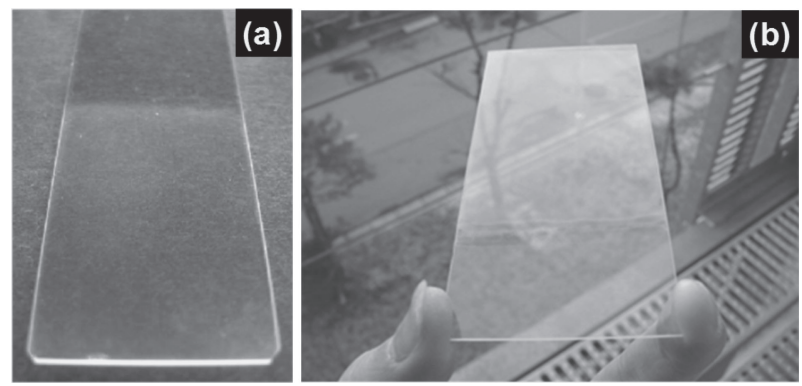

Fig. 3. Thin films of (a) $\mathrm{ZnO}_{2}$ and (b) $\mathrm{ZnO}$ on glass slides.

\section{Enzyme-mediated precipitation and morphology control}

Some enzymes catalyze the production of precipitants of metal ions. As an example, urease catalyzes the hydrolysis of urea to produce ammonia and carbonate ion, either of which can precipitate metal hydroxides or metal carbonates [Eq. (5)]. Similarly, alkaline phosphatase assists the hydrolysis of phosphate esters to produce inorganic phosphoric acid [Eq. (6)] that may precipitate metal phosphates, and peptidase can produce a carboxylic acid [Eq. (7)] that may act as precipitate of a metal carboxylate such as oxalate.

$$
\begin{aligned}
& \mathrm{H}_{2} \mathrm{NCONH}_{2}+4 \mathrm{H}_{2} \mathrm{O} \rightarrow 2 \mathrm{NH}_{4}^{+}+2 \mathrm{OH}^{-}+\mathrm{H}_{2} \mathrm{CO}_{3} \\
& \text { R-O- } \mathrm{PO}_{3} \mathrm{H}_{2}+\mathrm{H}_{2} \mathrm{O} \rightarrow \mathrm{ROH}+\mathrm{H}_{3} \mathrm{PO}_{4} \\
& \text { R-NHCO-R' }+\mathrm{H}_{2} \mathrm{O} \rightarrow \mathrm{RNH}_{2}+\mathrm{R}^{\prime}-\mathrm{COOH}
\end{aligned}
$$

So far, numerous kinds of ceramic materials have been synthesized including aluminum hydroxide, calcium carbonate, hydroxyapatite, magnetite, etc.

Some other enzymes can directly interact with water-soluble metal complexes or silicon alkoxides. For example, silicatein, lysozyme, papain, and catalase have been used to precipitate silica, titania, and other oxides. It is being elucidated that cationic moieties such as amino groups within the enzymes are responsible for the hydrolysis and subsequent condensation of metal complexes. The unique characteristics, advantages, and examples of ceramic materials prepared with the aid of enzymes as of the year 2010 have been comprehensively reviewed in an article ${ }^{6}{ }^{6}$ however, some other studies that were not included in the article will be described here. In addition to the assistance of the precipitation of ceramic materials, enzymes may play key roles in controlling morphology ${ }^{39)-46)}$ and crystalline polymorphs. ${ }^{47)}$ For example, the employment of urease for the precipitation of $\mathrm{CaCO}_{3}$ in polyelectrolyte capsules ${ }^{41)}$ or in the coexistence of magnesium $^{44)}$ or water-soluble polymers ${ }^{46)}$ affects the morphology and polymorph of the precipitant. The use of silicatein ${ }^{48), 49)}$ or silicatein-inspired synthetic polymers ${ }^{50), 51)}$ facilitates the site-selective deposition of $\mathrm{TiO}_{2}, \mathrm{SiO}_{2}$ or $\mathrm{SnO}_{2}$. Metallic nanoparticles can also be precipitated by the mediation of enzymatic reactions. Jiang's group developed a nanoparticle deposition method in which alkaline phosphatase catalyses the hydrolysis of ascorbic acid 2-phosphate, and the resultant ascorbic acid reduces $\mathrm{Cu}^{2+}$ or $\mathrm{Ag}^{+}$ions to metallic $\mathrm{Cu}$ or $\mathrm{Ag}{ }^{52), 53)}$ This technique may be applied to DNA biosensors. ${ }^{54), 55)}$ Another newly developed method is to use glucose oxidase $^{56)}$ to produce hydrogen peroxide from glucose and oxygen. The resultant hydrogen peroxide reduces $\mathrm{Au}^{3+}$ ions to $\mathrm{Au}$ nanoparticles.

One advantage of the mediation of enzymes is a fact that these enzymes are easily immobilized in or on templates so that the resultant ceramic precipitates conform to the templates. In other words, site-selective ceramic deposition is easily conducted. For example, when urease-bearing alginate gel particles are added to a solution containing aluminum sulfate and urea, precipitation of aluminum hydroxide proceeds only within the gel particles, which results in the formation of a precursor of porous alumina with a narrow pore size distribution. ${ }^{57)}$ Also when urease-bearing poly(divinylbenzene) particles are soaked in solutions containing iron sulfate or calcium phosphate with urea, deposition of iron hydroxide or calcium phosphate occurs selectively on the surface of the polymer particles, from which hollow ceramic particles can be prepared after eliminating the template particles by calcination ${ }^{58), 59)}$ (Fig. 4). 

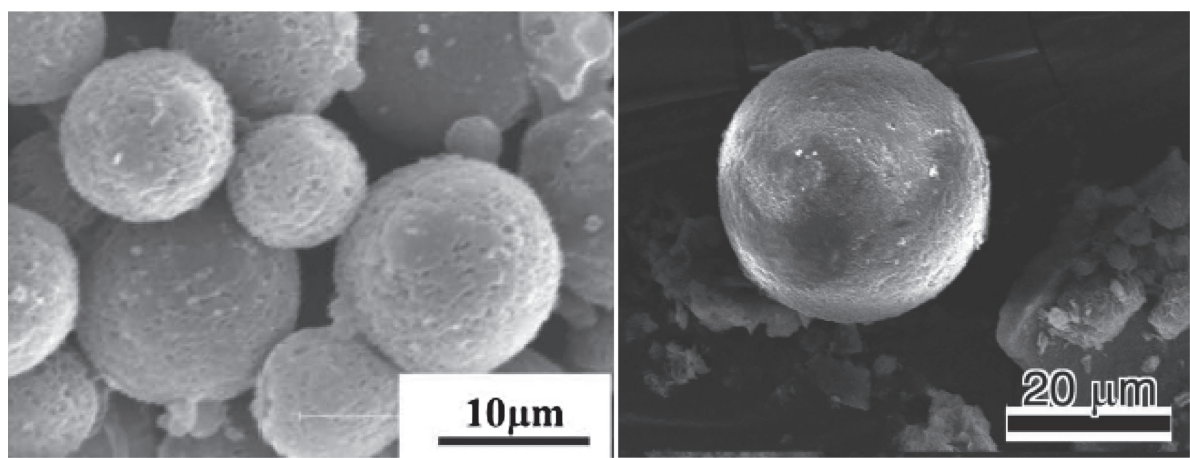

Fig. 4. Hollow magnetite and hydroxyapatite microspheres prepared using urease-bearing polymer beads as templates. Reprint from Refs. 58 and 59 with permission from Ceram. Soc. Japan.

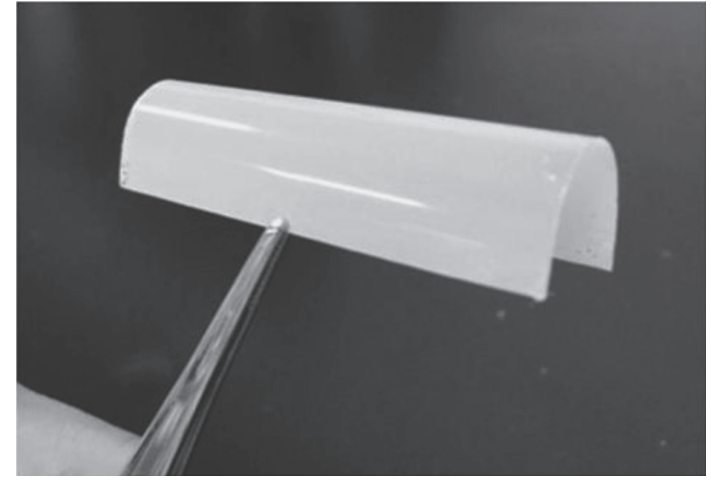

Fig. 5. Appearance of PET/gelatin/calcium phosphate composite sheet. Reprint from Ref 61 with permission of Jpn. Soc. Oral Implantology.

The present author's group has prepared calcium phosphate $(\mathrm{CaP})$ coatings by the mediation of urease on gelatin-coated poly(ethylene terephthalate) (PET) sheet, which will be denoted as $\mathrm{PET} / \mathrm{gel} / \mathrm{CaP}$, and investigated its in vitro ${ }^{60)}$ and in vivo ${ }^{61)}$ biological efficacy. Figure 5 shows the appearance of the sheet. The CaP layer extensively promoted the proliferation of MC3T3E1 cells and extracellular mineralization. The PET/gel/CaP sheet also promoted the new bone formation when it was placed on the extraction cavities of Beagle dogs. Figure $\mathbf{6}$ compares the histological thin sections of the alveolar bones of a Beagle dog with and without the guided bone regeneration (GBR) treatment with the PET/gel/CaP sheet. When the sheet was used for GBR, extensive new bone formation is recognized within and around the extraction cavity, implying the present $\mathrm{PET} / \mathrm{gel} / \mathrm{CaP}$ sheet may be a promising candidate for GBR membrane. The same coating was evidenced to assist new bone formation in diabetic rats which are known to have disabilities in bone metabolism. ${ }^{62)}$

The enzyme-mediated calcium phosphate coatings consist of low-crystallinity hydroxyapatite reflecting the low precipitation temperature $(310 \mathrm{~K})$, which may lead to quick dissolution of the calcium phosphate layer to the surrounding culture media or body fluid, resulting in the activation of osteoblasts and new bone formation. On the other hand, $\mathrm{CaP}$ layers with high crystallinity did not activate osteoblasts as much as enzyme-mediated $\mathrm{CaP}$ layers.

\section{Summary and future outlook}

Among enormous amount of works concerning aqueous solution processing, some topical categories have been picked
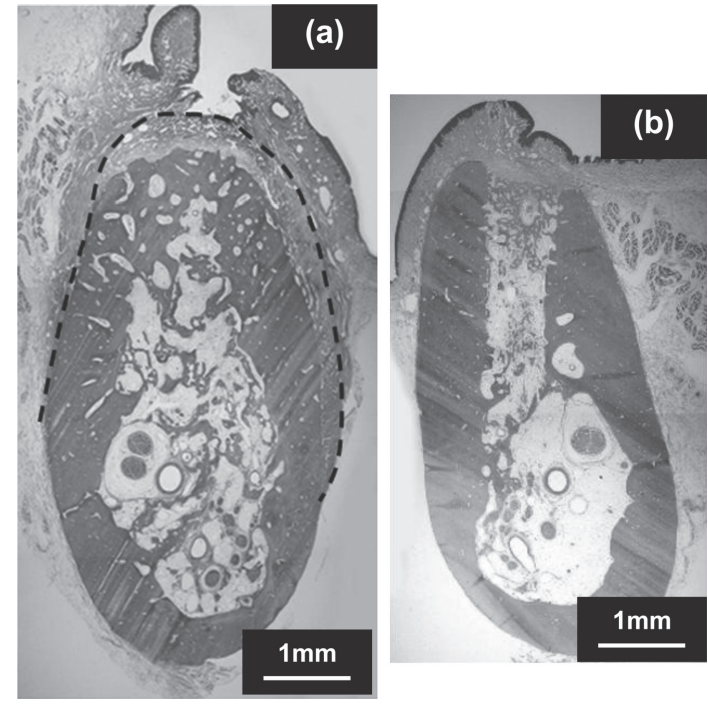

Fig. 6. Histological thin sections of alveolar bones of a Beagle dog 30 days after the extraction of teeth (a) with and (b) without guided bone regeneration assisted by PET/gelatin/calcium phosphate composite sheet. Dashed line in (a) indicates where the sheet was implanted. Reprint from Ref 61 with permission of Jpn. Soc. Oral Implantology.

up in this article. Ceramic thin films can be deposited in aqueous solutions by employing spontaneous precipitation reactions under optimum conditions. A wide variety of chemical reactions can be employed for thin film deposition and the use of porogen molecules can control the nano-structure of the resultant thin films. Enzyme-mediated ceramic synthesis may bring us new type of hybrid or composite materials as ceramic products are deposited in a site-selective manner under very mild conditions.

A diverse range of chemical reactions and physical phenomena occurring in aqueous solutions are available for ceramic synthesis. The controllability of macroscopic and microscopic structures is one of the advantages of aqueous solution processing. Another competitive edge is benignity to environments, on which more emphasis is to be added. The third benefit is the easiness of hybridizing ceramics with polymers or metals, and PETbased GBR membrane is an example. In addition, a wide variety of application seems to be at hand such as biosensing, photocatalysts, nanopowders, coatings, and biomedical materials. A single success often sets off many others, and the same shall be the case in the aqueous solution processing. 


\section{References}

1) T. P. Niesen and M. R. DeGuire, J. Electroceram., 6, 169-207 (2001).

2) T. P. Niesen and M. R. DeGuire, Solid State Ionics, 151, 61-68 (2002).

3) Y. Gao and K. Koumoto, Cryst. Growth Des., 5, 1983-2017 (2005).

4) H. Parikh and M. R. DeGuire, J. Ceram. Soc. Japan, 117, 228235 (2009).

5) T. Kawano and H. Imai, J. Ceram. Soc. Japan, 118, 969-976 (2010).

6) H. Unuma, Y. Matsushima and T. Kawai, J. Ceram. Soc. Japan, 119, 623-630 (2011).

7) M. Abe and Y. Tamaura, Jpn. J. Appl. Phys., Part 2, 22, L511L513 (1983).

8) M. Abe, T. Ito and Y. Tamaura, Thin Solid Films, 216, 155-161 (1992).

9) N. Matsushita, K. Kondo, S. Yoshida, M. Tada, M. Yoshimura and M. Abe, J. Electroceram., 16, 557-560 (2006).

10) H. Wagata, N. Ohashi, T. Taniguchi, K. Katsumata, K. Okada and N. Matsushita, Cryst. Growth Des., 10, 4968-4975 (2010).

11) H. Unuma, H. Takabatake, K. Watanabe, T. Ogata and $M$. Sugawara, J. Mater. Sci. Lett., 21, 1241-1243 (2002).

12) H. Unuma, H. Takabatake, S. Takeda, M. Sakai, K. Watanabe and M. Sugawara, J. Mater. Sci. Lett., 22, 1259-1261 (2003).

13) H. Unuma, T. Kanehama, K. Yamamoto, K. Watanabe, T. Ogata and M. Sugawara, J. Mater. Sci., 38, 255-259 (2003).

14) H. Unuma, Y. Saito, K. Watanabe and M. Sugawara, Thin Solid Films, 468, 4-7 (2004).

15) Y. Saito, K. Kaga, M. Tsutsumida and H. Unuma, Chem. Lett., 34, 1202-1203 (2005).

16) A. Varkey and A. F. Fort, Thin Solid Films, 235, 47-50 (1993).

17) K. Tsukuma, T. Akiyama and H. Imai, J. Am. Ceram. Soc., 84, 869-871 (2001).

18) H. Unuma and Y. Matsushima, J. Jpn. Soc. Powder Powder Metallurgy, 59, 313-319 (2012) [in Japanese].

19) L. Vayssieres, Adv. Mater., 15, 464-466 (2003).

20) M. Izaki and Y. Saijo, J. Electrochem. Soc., 159, C73-C76 (2003).

21) M. Izaki and O. Shinoura, Adv. Mater., 13, 142-145 (2001).

22) M. Izaki, T. Saito, M. Chigane, M. Ishikawa, J. Katayama, M. Inoue and M. Yamashita, J. Mater. Chem., 11, 1972-1974 (2001).

23) H. Nagayama, H. Honda and H. Kawahara, J. Electrochem Soc., 135, 2013-2016 (1988).

24) S. Deki, Y. Aoi, O. Hiroi and A. Kajinami, Chem. Lett., 25, 433-434 (1996).

25) Y. Gao, Y. Masuda, Z. Peng, T. Yonezawa and K. Koumoto, J. Mater. Chem., 13, 608-613 (2003).

26) S. Yamabi and H. Imai, Chem. Mater, 14, 609-614 (2002).

27) Y.-F. Gao, M. Nagai, W. S. Seo and K. Koumoto, Langmuir, 23, 4712-4714 (2007).

28) S. Deki, S. Iizuka, A. Horie, M. Mizuhata and A. Kajinami, J. Mater. Chem., 14, 3127-3132 (2004).

29) Y. Gao, Y. Masuda, H. Ohta and K. Koumoto, Chem. Mater., 16, 2615-2622 (2004).

30) K. Kuratani, M. Uemura, M. Mizuhata, A. Kajinami and S. Deki, J. Am. Ceram. Soc., 88, 2923-2927 (2005).

31) S.-H. Baeck, T. F. Jaramillo, G. D. Stucky and E. W. McFarland, Chem. Mater., 15, 3411-3413 (2003).

32) Y. Gao, Y. Masuda, T. Yonezawa and K. Koumoto, Chem. Mater., 14, 5006-5014 (2002).

33) Y. Saito, T. Shiga, A. Kokubun, T. Kawai and H. Unuma, J. Ceram. Soc. Japan, 115, 938-940 (2007).

34) J. J. Richardson and F. F. Lange, Cryst. Growth Des., 9, 2570-
2575 (2009).

35) J. J. Richardson and F. F. Lange, Cryst. Growth Des., 9, 25762581 (2009).

36) D. Andeen, J. H. Kim, F. F. Lange, G. K. L. Goh and S. Tripathy, Adv. Funct. Mater., 16, 799-804 (2006).

37) B. Nijikovsky, J. J. Richardson, M. Garbrecht, S. P. DenBaars and W. D. Kaplan, J. Mater. Sci., 48, 1614-1622 (2013).

$38)$ S. Y. Park, B. J. Kim, K. Kim, M. S. Kang, K.-H. Lim, T. I. Lee, J. M. Myoung, H. K. Baik, J. H. Cho and Y. S. Kim, $A d v$. Mater., 24, 834-838 (2012).

39) C. Jimenez-Lopez, A. Rodriguez-Navarro, J. M. Dominguez-Vera and J. M. Garcia-Ruiz, Geochim. Cosmochim. Acta, 67, 1667-1676 (2003).

40) K. Hayashi, M. Nakamura, W. Sakamoto, T. Yogo, T. Kori and K. Ishimura, Chem. Mater., 23, 3341-3347 (2011).

41) A. Antipov, D. Shchukin, Y. Fedutik, I. Zanaveskina, V. Klechkovskaya, G. Sukhorukov and H. Möhwald, Macromol. Rapid Commun., 24, 274-277 (2003).

42) S. D. Škapin and I. Sondi, Cryst. Growth Des., 5, 1933-1938 (2005).

43) S. Vial, J. Ghanbaja and C. Ferano, Chem. Commun., 290-292 (2006).

44) I. Sondi, S. D. Škapin and B. Salopek-Sondi, Cryst. Growth Des., 8, 435-441 (2008).

45) Z. Zhuang, H. Yamamoto and M. Aizawa, Powder Technol., 222, 193-200 (2012).

46) D. N. Cacace and C. D. Keating, J. Mater. Chem. B, 1, 17941803 (2013).

47) X. Wang, H. Sun, Y. Xia, C. Chen, H. Xu, H. Shan and J. R. Lu, J. Colloid Interface Sci., 332, 96-103 (2009).

48) M. N. Tahir, F. Natalio, H. A. Therese, A. Yella, N. Metz, M. R. Shah, E. Mugnaioli, R. Berger, P. Theato, H. C. Schröder, W. E. G. Müller and W. Tremel, Adv. Funct. Mater., 19, 285291 (2009).

49) R. André, M. N. Tahir, H. C. C. Schröder, W. E. G. Müller and W. Tremel, Chem. Mater., 23, 5358-5365 (2011).

50) C. C. Hire, H. C. Genuino, S. L. Suib and D. H. Adamson, Chem. Mater, 25, 2056-2063 (2013).

51) C. C. Hire, A. J. Oyer, G. E. Macek, J. L. Bento and D. H. Adamson, J. Mater. Chem. B, 1, 1977-1984 (2013).

52) Y. Huang, Q. Wen, J.-H. Jiang, G.-L. Shen and R.-Q. Yu, Biosens. Bioelectron., 24, 600-605 (2008).

53) Y. Huang, T.-H. Wang, J.-H. Jiang, G.-L. Shen and R.-Q. Yu, Clin. Chem., 55, 964-971 (2009).

54) H. Tan, S. Yang, G. Shen, R. Yu and Z. Wu, Angew. Chem., Int. Ed., 49, 8608-8611 (2010).

55) J. Liu, X. Yuan, Q. Gao, H. Qi and C. Zhang, Sens. Actuators, $B, 162,384-390$ (2012).

56) H. Zhang, R. Liu, Q. Sheng and J. Zheng, Colloids Surf., B, 82, 532-535 (2011).

57) H. Unuma, Y. Hirose, M. Ito and K. Watanabe, J. Ceram. Soc. Japan, 112, 409-411 (2004).

58) T. Kawai, H. Sekikawa and H. Unuma, J. Ceram. Soc. Japan, 117, 340-343 (2009).

59) J. Zhao, H. Sekikawa, T. Kawai and H. Unuma, J. Ceram. Soc. Japan, 117, 344-346 (2009).

60) T. Furusawa, M. Sato, T. Okudera, Y. Matsushima and H. Unuma, J. Jpn. Soc. Oral Implantology, 25, 699-707 (2012) [in Japanese].

61) T. Furusawa, T. Okudera, Y. Matsushima and H. Unuma, J. Jpn. Soc. Oral Implantology, 26, in press. (2013) [in Japanese]

62) J. B. Kim, T. Furusawa, T. Okudera, W. Yan, K. Monma, Y. Matsushima, H. Unuma and T. Sasano, J. Ceram. Soc. Japan, 120, 589-593 (2012). 


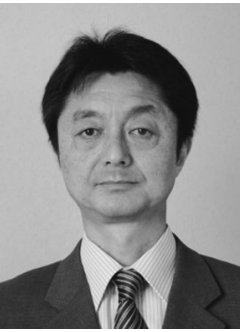

Hidero Unuma is a Professor of the Department of Chemistry and Chemical Engineering, Graduate School of Science and Engineering, Yamagata University, Japan. He received his B. Sci. (1982) at Tohoku University and his Ph.D. (1993) at Kyoto University. He worked for Government Industrial Development Laboratory at Hokkaido, and then became an associate professor at Nagoya Institute of Technology. He became a Full Professor at Yamagata University in 2008. 